JEL: L52, 014, 025.

DOI: 10.5937/industrija44-12011

UDC:338.45.027(4-672EY)"2020"

Scientific Review

\title{
Changes of EU Industrial Policy and its Effects on Romania's Industrial Paradigm
}

\author{
Article history: \\ Received: 10 August 2016 \\ Sent for revision: 3 September 2016 \\ Received in revised form: 11 November 2016 \\ Accepted: 13 November 2016 \\ Available online: 30 December 2016
}

\begin{abstract}
Latest developments on the international markets create new challenges for the old way of industrial production and development. As the developing countries take the share of important players from the EU it is more and more visible the need for a change of the industrial policy. The advance in technology and the way we produce goods it's changing and the need for more advanced and more customized products is growing. The idea that there is no need for industrial policy and the believe that the market must be felt free is also loosing supporters in front of new actors from countries with a strong targeted industrial policy which get higher and higher market shares.
\end{abstract}

Keywords: industrial policy, development, growth, Europe 2020.

\section{Promene industrijske politike EU i njen uticaj na industrijsku paradigmu Rumunije}

Apstrakt: Najnoviji događaji na međunarodnim tržištima stvaraju nove izazove starom načinu industrijske proizvodnje i razvoja. Kako zemlje u razvoju sve više učestvuju kao važni igrači iz EU, to je sve očiglednija potreba za promenom industrijske politike. Napredak u tehnologiji i način na koji proizvodimo robu se menjaju, a potreba za naprednijim $i$ prilagođenijim proizvodima raste. Ideja da nema potrebe za industrijskom politikom $i$ uverenje da se tržište mora osetiti slobodnim takođe gube svoje pristalice pred novim akterima iz zemalja sa jakom ciljanom industrijskom politikom koje dobijaju sve veće tržišno učešće.

Ključne reči: industrijska politika, razvoj, rast, Evropa 2020.

\footnotetext{
${ }^{1}$ Petroleum-Gas University of Ploiesti, Romania, catalin.voica@upg-ploiesti.ro 
Cătălin V.M..: Changes of EU Industrial Policy and its Effects on Romania's Industrial..

\section{Introduction}

The European Union (EU) industry passes through a hard time because too much time passed with no active industrial policy to drive it forward in a logical direction. This became obvious after the financial crisis stroke and the new players like China, South Asia and Latin America, backed by powerful industrial policies implemented by their governments, flourished while the industry in Western economies declined.

Until recent years, it was considered that there was no need for an industrial policy, but facts proved that an industry without targets and support from policymakers will eventually loose in front of competitors that benefit from an integrated policy. After this became clear, the problem ahead is to choose the best way to create and implement the industrial policy and to see where it should be focused. The "pick the winners" policy or the creation of strong state-owned companies used in the past is not suitable for the actual economic environment of the EU.

Specific sector or industry targeted policies are considered to generate a reduction of firms' competitiveness and investments (Farla, 2015). Even so industrial policy is re-emerging in the form of specific sector and industry support by the governments of developed countries (Aiginger, 2007). Latin American countries have a long period of proactive industrial policy combined with a promotion of exports (Peres, 2009).

The main issue with industrial policy is its mixed results in different parts of the world. Almost all developing countries used a form of industrial policy (Chang, 2002) to advance its industrial base in order to become competitive on the international market. The success of industrial policy in East Asia that generated the remodeling of industry by changing its structure and the emergence of new industries is offset by the problems generated in developing countries and advanced economies where it is synonymous with "white elephants, rent-seeking and good money spent after bad" (Rodrik, 2014) being more rewarding with some individuals and firms (Pack and Saggi, 2006). Even though the industrial policy had its failures like Concorde in France or the powerful state owned companies like ENI in Italy, it generated a powerful boost for development and cooperation like the Airbus in Europe or the Silicon Valley in US (Block and Kneller, 2011). According to Mazzucato (2013), all key technologies incorporated in the iPhone received a form of public funding at some phase of its development.

According to Rodrick (2014) there are two main cons to industrial policy. The first one is that the governments don't have access to suitable information in order to drive its funds to the most efficient firms or industries. In line with this con we find the old policy of "picking the winners" which demonstrated that the 
Cătălin V.M..: Changes of EU Industrial Policy and its Effects on Romania's Industrial..

governments do a lot of mistakes and in the process waste a lot of funds. The second one is that by supporting one industry, they will attract "rent-seeking and political manipulation by well-connected firms and lobbyists" (Rodrik, 2014). The industrial policy can suffer by political interference as North et al. (2009) promote the idea that elites maintains political stability by distributing rents and, in return, protect their own prosperity. Some industrial policy reforms were influenced by the private sector through ensuring political support (Rodrik and Subramanian, 2005). The market liberalization, as opposite to industrial policy, ensured the re-distribution of rents to elites through privatization and restructuring for market development (Schamis, 2002). Also, the anti-competition policy absence may prove that pressure is generated by the elites to keep the dominance over the industry (Acemolglu et al, 2006)

The financial crisis of 2008 brought in attention the high level of disparities between two groups of countries that form the EU, the highly developed countries from the center of the EU with Germany as the main driver and the countries from the periphery less developed. For many years the center countries benefits from exports to the periphery and by doing so they improved their industrial and R\&D advance at the cost of maintaining a low level of industrial development in periphery countries. The financial crisis generated a high reduction of imports for periphery countries which in turn prevented the imbalances of current accounts. According to Pianta (2014), there will be an increase of trade imbalances in many EU countries as a result of the loss of intern industrial capacity, which, in turn, may generate losses of incomes, production, jobs and exports.

\section{Some aspects regarding the new Europe 2020 strategy}

In 2010 the EU released Europe 2020 the strategy for smart, sustainable and inclusive growth (COM 2020, 2010). This strategy was fostered on the acknowledgement that the financial crisis had an important impact on the economic and social progress and revealed Europe's economic weaknesses. In order to surpass these problems, the strategy concentrates on three priorities: smart growth - to develop an economy based on knowledge and innovation, sustainable growth - to promote a more resource efficient, greener and more competitive economy and at last inclusive growth - to foster a high-employment economy delivering social and territorial cohesion. These strategies stated five headline targets which need to be accomplished by 2020 and seven flagship initiatives to foster progress under each priority theme. 
Cătălin V.M..: Changes of EU Industrial Policy and its Effects on Romania's Industrial..

One of these flagship initiatives is an industrial policy for the globalization era with the role to create a framework to tackle all the problems from the access to raw materials to international value chains to after sale service. According to this initiative the EU will take a horizontal approach to industrial policy with the use of different policy instruments in order to establish an industrial policy to create and maintain a strong, competitive and diversified industrial base in Europe (COM 614, 2010). The EU considers as inefficient the use of targeted policies used in the past because of the difficulty of selecting and evaluating the right participants (Lerner, 2009). As a result, the EU has only a few policy tools at its disposal, like:

- Structural funds with the role of reducing regional imbalances by compensating the losers, they are co-financed by national governments or local authorities and used for infrastructure, support local development, education and training ;

- Smart Specialization mitigates for horizontal funding to create a critical mass of R\&D, innovation and the capacity to drive investments into highly specialized activities that include advanced technologies and local competences (Foray et all, 2009).

- The European Investment Bank funds an array of private and public projects. However, the EIB operates in the boundaries of financial institutions and has to comply with requirements like profitability, bond rating, low risk and short time frames.

- EU Commission regulatory activity has an impact in some specific fields like food, environment, health, safety and culture, but the regulations are not enough to generate a reshaping of an industry.

However, this horizontal approach had a minimal impact on the development of production capacity. After the 2008 financial crisis, the discussions regarding macroeconomical and fiscal consolidation derailed in the context of austerity measures taken by the governments of the Euro-zone and as a result the debate on industrial policy stopped.

Now, the 2020 strategy follows the neoliberal view which states that fiscal consolidation, debt reduction and market operations generate a long term growth. In the Europe 2020 interpretation, these are generated by the so called "growth enhancing items" like R\&D and innovation. In order to do this there have to be some cuts in the social expenditures that became unsustainable in the new view (COM 2020, 2010; COM 546 final, 2010). 
Cătălin V.M..: Changes of EU Industrial Policy and its Effects on Romania's Industrial..

\section{Europe's new industrial policy}

The EU has high market shares in some important sectors of the industry like pharmaceutical and aeronautics. Even though the EU industry is highly competitive in some sectors, the growth rates are below the US or the emerging countries. The EU share of high-tech product exports is decreasing for some time and as a result the EU industry transformed itself in a mid-tech products production base. According to Eurostat in the last ten years the share of EU manufactures exports in global volume trade has decreased from $19 \%$ to $16 \%$.

Those numbers cast a shadow on the future of mid and long-term industrial development in the EU. Different authors view the future in different ways. One view is that the convergence to the new green energy and the intelligent networking of information and energy systems will generate more decentralized patterns for industrial production (Rifkin, 2011). Other view considers that informational highways will catalyze the decentralization of design and consumption and a superior concentration of production plants with the highest flexibility in order to produce low number of customized products with less stress on the energy problems (Anderson, 2012). A study from the American Institute for Defense Analysis realized in collaboration with many experts concluded that the present and future reshaping of manufacturing industry is influenced by factors like: information technology, increase of modeling and simulation in manufacturing process, fast innovation of global supply-chain management, quick response to customer needs by modifying the manufacturing process and increase support for sustainable manufacturing (IDA, 2012).

The latest release from the European Commission, for an European Industrial Renaissance, states that in the current social, economic and environmental conditions "EU companies cannot compete on low price and low quality products" and as a result, to compete in the global market "they must turn to innovation, productivity, resource-efficiency and high valueadded" (COM 14 final, 2014). This is why the EU has to put all its efforts to reach the $3 \%$ of GDP of spending in R\&D as is also stated in the Europe 2020 strategy.

In order to stimulate investments in innovation and new technologies the EU uses the Horizon 2020 Programme which will infuse almost 80 billion EUR in research and innovation along with another 100 billion EUR from 2014-2020 European Structural and Investment Funds (ESIF). These funds will be used by the member states to speed up investments in cutting edge technologies in the six cross-cutting areas identified by the Commission in the 2012 Industrial 
Cătălin V.M..: Changes of EU Industrial Policy and its Effects on Romania's Industrial..

Policy Communication. As a result the Commission will follow the next priorities (COM 14 final, 2014):

- Advance manufacturing will promote the use of knowledge and innovation on value-added manufacturing to generate a sustainable industry through the use of resource and energy efficiency by upgrading the innovation capacity and competitiveness of the EU manufacturing sector,

- Key Enabling Technologies (KETs) will identify the potential KETs projects of European interests like batteries, intelligent materials, high performance production and industrial bio-processes,

- Bio-based products, which will allow access to sustainable raw materials for the production of bio-based products,

- Clean Vehicles and Vessels will implement the Green Vehicle Initiative and other H2020 initiatives that promotes clean and energy efficient transport,

- Sustainable construction and raw materials will consist of a 25 billion EUR lending capacity from EIB for energy efficiency and residential housing, recycling and sustainable waste management in construction,

- Smart Grid and Digital Infrastructures will define the targets for development of smart grid components which should help integrate high performance processes.

For future development the EU must concentrate its efforts to sustain the economy and the industrial competitiveness by maximizing the potential of the internal market through the developing of necessary infrastructure. This can be achieved by integrating capital markets, promoting entrepreneurship and innovation sustained by a favorable, simplified and predictable policy. The EU must implement the necessary instruments which support innovation, skills and entrepreneurship with the role to deliver industrial change and support for an increased competitiveness of the EU economy.

\section{New industrial policy in Romania}

Romania passed through a process of deindustrialization after the change of regime in 1989. As a result the industry of Romania regressed drastically in the following period. The evolution of the national economy largely reflected the effects of a long process of reform and economic restructuring which had the main objective of making a strong centralized socialist economy to a 
Cătălin V.M..: Changes of EU Industrial Policy and its Effects on Romania's Industrial..

market economy that works on the principles of economic democracy (Andrei \& Ungureanu, 2014) As the transition process passed many of the industrial entities that should have been privatized and continue their businesses, disappeared under the ownership of ruthless capitalist or petty thieves that used corruption as their tool to grease the wheels of local authorities in order to gain control over them. This took place under the national trend to promote a preferential treatment for foreign investors (Matei, 2004).

This state of fact remained unchanged until the years 2000 when the policies regarding the investments realized in Romania changed and the positive discrimination of foreign investors disappeared. After years of deindustrialization and chaotic economic evolution Romania finally stopped this process and began to stabilize its macroeconomic indicators (Zaman et al, 2011). This is the moment when Romania started to walk on the road towards EU integration. This happened in 2007 after years of struggle towards convergence to the EU Acquis. Just one year after Romania became an EU member, the international financial crisis started and entire EU went in a steep depression.

Now Romania is trying to find its road towards a new period of industrial development in the context of the new industrial policy of the EU. For 25 years the continuous industrial restructuration and relocation of productive capacities from abroad to Romania and forward from Romania to other countries had important repercussions on some industrial sectors which have been decimated (lacovoiu \& Panait, 2014). This had a dramatic effect on local population and as a result deindustrialization became an instrument of depopulation of certain mono industrial areas like those from the mining sector.

Even though all this happened Romania remained the second ranking state regarding the share of industrial activities in GDP according to Eurostat, with a share of $26 \%$ in 2010. This ranking is generated by the low level of development of services and the future development must be focused on both sectors to generate a harmonious and sustainable development.

The actual state of Romania's industry can be evaluated by reviewing the dynamic of the number of enterprises by the level of technology they use. 
Cătălin V.M..: Changes of EU Industrial Policy and its Effects on Romania's Industrial..

Figure 1 Number of enterprises in manufacturing in Romania

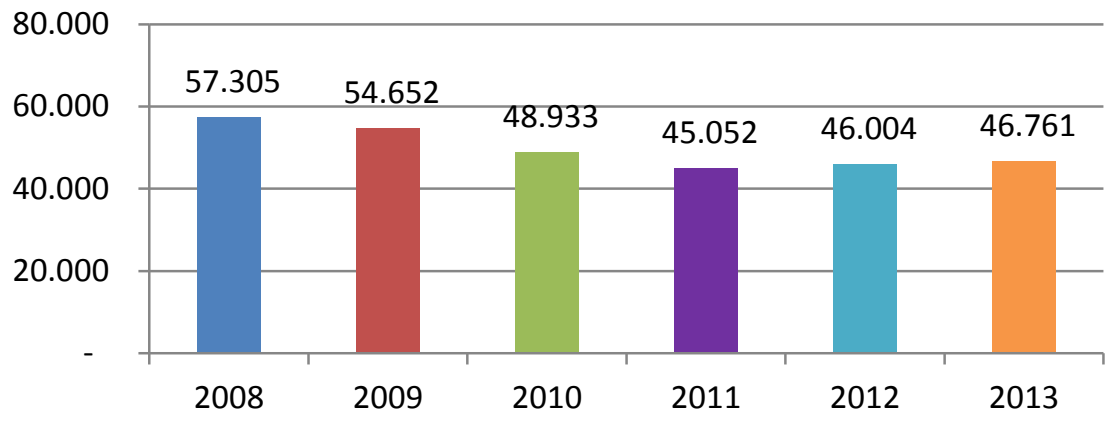

Source: Eurostat

In Fig. 1 we can observe the dynamic of the number of enterprises engaged in manufacturing in the post-crisis period of 2008-2013 which can be divided in two periods characterized by two trends:

- 2008-2011, the period when almost $22 \%$ of enterprises engaged in manufacturing activity disappeared because of the hard economic environment characterized by the loss of local and foreign markets and the actions of national government mainly with the introduction of the flat tax.

- 2011-2013, the period when the economy started to recover on the background of a new political regime that took a lot of liberal decisions which catalyzed the development of the economy and created a favorable medium for new enterprises to be born.

Forward we look at the dispersion of the enterprises on different level of technologies and we research the most important of them like those from high-technology, medium high-technology and medium-low technology. In Fig.2 we can observe the evolution of the enterprises that use these levels of technologies in their manufacturing process. The first thing worth mentioning is that the enterprises from high-technology manufacturing and medium hightechnology manufacturing were affected first by the international financial crisis while those from medium low-technology manufacturing kept the growing trend from the pre-crisis period until 2009. This had a cost because until 2011 the number of enterprises from the medium low-technology manufacturing dropped with around $18 \%$, while the number of enterprises from medium high-technology manufacturing dropped with $15 \%$ and the number of enterprises from high-technology manufacturing dropped with $27 \%$. 
Cătălin V.M..: Changes of EU Industrial Policy and its Effects on Romania's Industrial..

Figure 2 Number of enterprises in High-technology manufacturing, Medium high-technology manufacturing and Medium low-technology manufacturing in Romania

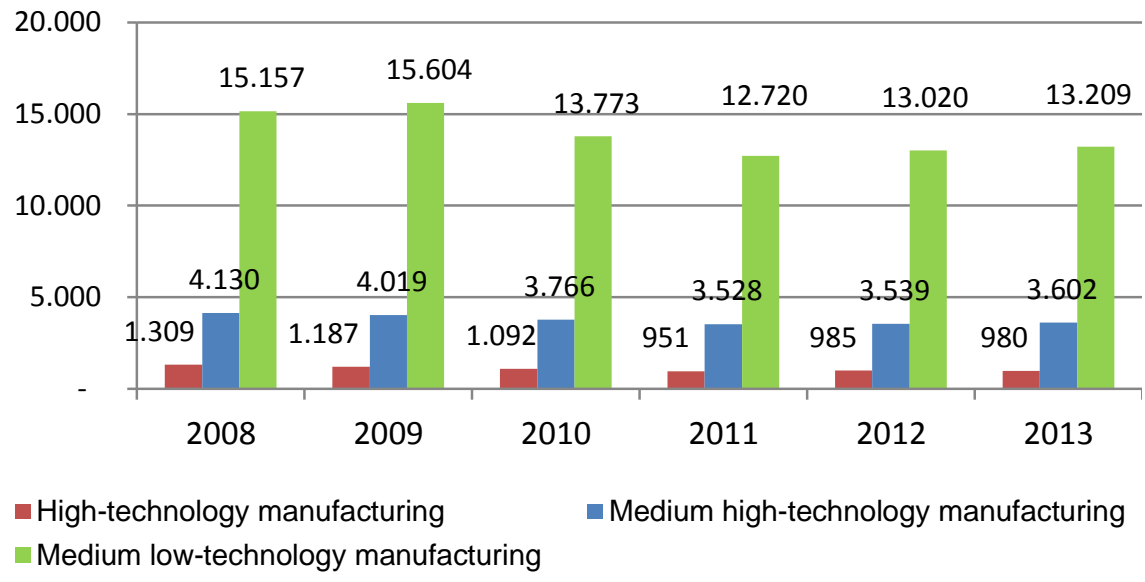

Source: Eurostat

As we can see the high-technology manufacturing sector has been the most affected, because the cutting edge technologies don't have an established market and require a high degree of risk taking by the investors. The first effect of the financial crisis was to undermine the market systems, to create low level of confidence between partners and to increase the risk of investments.

After 2011 the number of companies from these manufacturing sectors began to grow slowly as the country and international markets began to recover after the depression. In the context of the new industrial policy of the EU we find ourselves in a disadvantage with a low and medium low technology manufacturing base. As a consequence, we need to use at the full potential the funding from the EU to create more high-technologies manufacturing enterprises in order to grow the technological level of Romania's goods and to conquer new markets.

Another important aspect regarding Romania's economy and its level of technological development can be estimated by observing the dynamic of $R \& D$ expenditures per inhabitant and comparing it with the average of the EU28 member states. In order to do that we observed the data presented in Table 1 which depicts the evolution of R\&D expenditures for the period of 2005 to 2014 broken by main sectors like Business enterprises sector, Government sector, Higher Education sector and Private non-profit sector. 
Cătălin V.M..: Changes of EU Industrial Policy and its Effects on Romania's Industrial..

Table 1. Total intramural R\&D expenditure (GERD) by sectors of performance in Romania (Euro/inhabitant)

\begin{tabular}{|c|c|c|c|c|c|}
\hline Year & $\begin{array}{c}\text { All } \\
\text { sectors }\end{array}$ & $\begin{array}{c}\text { Business } \\
\text { enterprise } \\
\text { sector }\end{array}$ & $\begin{array}{c}\text { Government } \\
\text { sector }\end{array}$ & $\begin{array}{c}\text { Higher } \\
\text { education } \\
\text { sector }\end{array}$ & $\begin{array}{c}\text { Private } \\
\text { non-profit } \\
\text { sector }\end{array}$ \\
\hline 2005 & 15.3 & 7.6 & 5.2 & 2.1 & 0.4 \\
\hline 2006 & 20.9 & 10.1 & 6.8 & 3.7 & 0.3 \\
\hline 2007 & 30.9 & 12.9 & 10.5 & 7.4 & 0.1 \\
\hline 2008 & 39.2 & 11.8 & 16.1 & 11.3 & 0.1 \\
\hline 2009 & 27.2 & 10.9 & 9.5 & 6.7 & 0 \\
\hline 2010 & 28.2 & 10.8 & 10.4 & 6.9 & 0.1 \\
\hline 2011 & 32.5 & 11.7 & 13.3 & 7.4 & 0.1 \\
\hline 2012 & 32.1 & 12.5 & 13.1 & 6.3 & 0.1 \\
\hline 2013 & 27.9 & 8.5 & 13.7 & 5.5 & 0.1 \\
\hline 2014 & 28.8 & 12 & 12.4 & 4.4 & 0.1 \\
\hline 2014 & 560.1 & 358.3 & 67.9 & 129.3 & 4.6 \\
(EU 28) & & & & & \\
\hline
\end{tabular}

Source: Eurostat

In the case of Romania the highest value for R\&D expenditures has been registered in 2008 with 39.2 Euro/inhabitant after four years of increases of around $64 \%$ every year from a value of 15.3 Euro/inhabitant in 2005 . After 2008 the value of R\&D expenditures oscillated between 27.2 and 32.5 Euro/inhabitant.

The distribution among sectors of the R\&D expenditures show us that around $80 \%$ of the expenditures are realized by the Business enterprises and Government sectors with almost the similar shares of total expenditures. The Higher education sector is the third with the rest of the share while Private non-profit sector is almost inexistent.

In Fig. 3 we have the evolution of the average of R\&D expenditures for the 28 member states of the EU. If we corroborate the information from Table 1 and Fig.1 we can see some important differences related to which sector spends what and how much on R\&D.

First, we observe that on 2014 the level of R\&D expenditures in Romania is only around $5 \%$ of the average of the EU which can explain the low number of enterprises in high-technology manufacturing. Second, the Business enterprise sector holds around $60 \%$ of total R\&D expenditures in the EU while in Romania it holds only around $40 \%$. Third, Higher education sector is the 
Cătălin V.M..: Changes of EU Industrial Policy and its Effects on Romania's Industrial..

second largest in the EU with around $20 \%$ of $R \& D$ expenditures while in Romania it only represents around $15 \%$, meaning that the intelligence of academics is not financed enough. Fourth, the Government sector spends only around $10 \%$ of total R\&D expenditures while in Romania it accounts for more than $40 \%$ of total $R \& D$.

Figure 3 Total intramural R\&D expenditure (GERD) by sectors of performance in EU-28 (Euro/inhabitant)

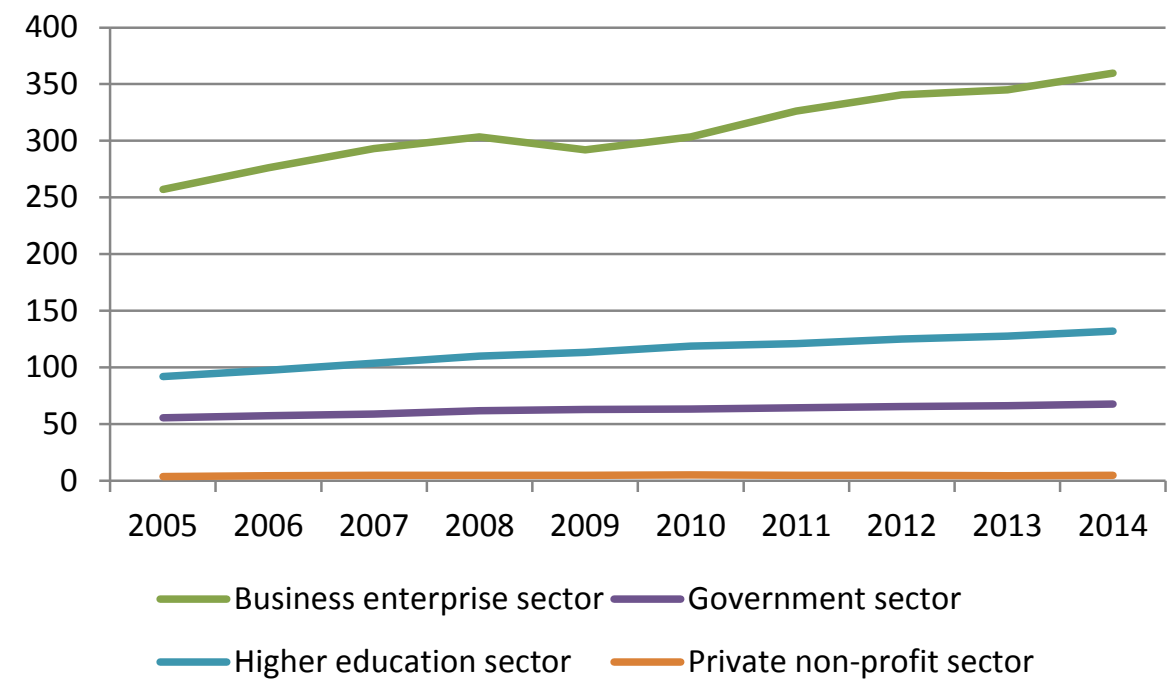

Source: Eurostat

\section{Conclusions}

Industrial policy proved in the last decade that it is a must and without it there will be no goal established to drive the industry forward and catalyze its development. Old industrial policies proved their unfitness in the new developing world and new types of policies need to be develop in order to insure the advance of the industrial base of a country or of a region.

The EU needs to enhance its policies regarding the industrial development in order to increase the technological level of its industrial base and to create new products that addresses the new desires of consumers. To do that the EU needs to promote the use of new technologies like $3 \mathrm{~d}$ printing and product customization to win the fight with other developed and developing economies 
Cătălin V.M..: Changes of EU Industrial Policy and its Effects on Romania's Industrial..

that are fast growing using new models of development and new managerial and marketing skills that emphasize with the idea of product customization, automated production, intelligence hubs, cluster development and so on.

Romania has a hard road ahead because it needs to recover the lost time with industry restructuring and privatization of former communist regime and to catch up with the developed countries of the EU. Romania needs to make a better use of the funds from the EU to improve the technological level of its industrial base and to rearrange the division of $R \& D$ expenditures at national level with a higher contribution from business enterprises and higher education sectors.

\section{References}

Andrei, J.V. Ungureanu, A. (2014), The importance of economic structure evolution in achieving performance - from agrarian economy to competitiveness in Romanian economy, Economics of Agriculture, 61, issue 4, 945-957

Aiginger, K. (2007), 'Industrial Policy: A Dying Breed or A Re-emerging Phoenix', Journal of Industry, Competition and Trade, 7(3), 297-323.

Anderson, C. (2012), Makers: The New Industrial Revolution, Crown Business Publishing, New York.

Block, F. R., and Keller, M. R. (eds) (2011), State of Innovation: The US Government's Role in Technology Policy, Paradigm Publishers.

COM (2010) 2020 final, EUROPE 2020 A strategy for smart, sustainable and inclusive growth

COM (2010) 614 final, An Integrated Industrial Policy for the Globalization Era Putting Competitiveness and Sustainability at Centre Stage

COM (2010) 546 final, Europe 2020 Flagship Initiative Innovation Union

COM (2014) 14: For a European Industrial Renaissance

Chang H-J (2002) Kicking Away the Ladder: Development Strategy in Historical Perspective. Anthem Press

Farla, K., (2015), Industrial Policy for Growth, Journal of Industrial Competition and Trade (2015) 15:257-282, DOI 10.1007/s10842-014-0183

Foray, D., David, P., Hall, B., (2009) Smart specialization: the concept. In Knowledge for Growth: Prospects for science, technology and innovation, Report. EUR24047, European Union pp.25-36

lacovoiu, V. B., \& Panait, M. (2014). „The Limitation of Investment Development Path Theory. European Union Case". Economic Insights-Trends and Challenges, 3 , 33-40.

Institute for Defense Analyses, 2012, Emerging Global Trends in Advanced Manufacturing

Lerner, J.(2009) Boulevard of Broken Dreams, Why Public Efforts to Boost Entrepreneurship and Venture Capital Have Failed and What to Do About it, Princeton University Press

Matei, M. (2004). Foreign direct investments. Functions and evolutions 1990- 2000, Expert Publishing House, Bucharest. 
Cătălin V.M..: Changes of EU Industrial Policy and its Effects on Romania's Industrial..

Mazzucato, M.,(2013) The Entrepreneurial State, Anthem Press, London

North DC, Wallis JJ, Weingast BR (2009) Violence and Social Orders: a conceptual framework for interpreting human history. Cambridge University Press, New York

Pack H, Saggi K (2006) The case for industrial policy: a critical survey. Policy Research Working Paper Series, No. 3839, The World Bank

Peres W (2009) The (Slow) Return of Industrial Policies. In: Cimoli M, Dosi G, Stiglitz JE (eds) Industrial Policy and Development. Oxford University Press, New York, pp 175-202

Pianta, M., (2014), An Industrial Policy for Europe. Seoul Journal of Economics; 27, 3; ProQuest Central

pg. 277

Pianta, Mario,(2014) An Industrial Policy for Europe, Seoul Journal of Economics; 27, 3

Rifkin, J. (2011), The Third Industrial Revolution: How lateral Power is Transforming Energy, the Economy and the World, Palgrave McMillan, New York

Rodrik, D., (2014) Green industrial policy, Oxford Review of Economic Policy, Volume 30, Number 3, pp. 469-491

Rodrik D, Subramanian S (2005) From Hindu Growth to Productivity Surge: the mystery of the Indian growth transition. IMF Staff Papers 52(2)

Schamis HE (2002) Re-forming the state: the politics of privatization in Latin America and Europe. University of Michigan Press, Ann Arbor

Zaman, G., Vasile, V., Matei, M., Croitoru, C., \& Enescu, G. (2011). Some challenging (macro) economic aspects of FDI in Romania. Romanian Journal of Economics, 2(42) 
